
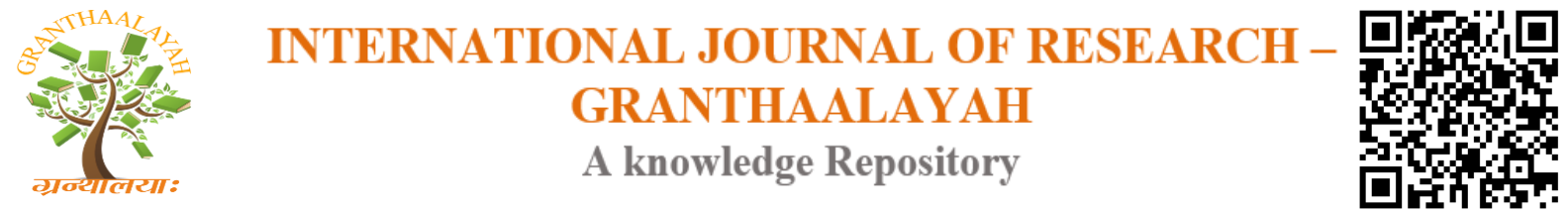

Science

\title{
EFFECTS OF DIFFERENT WEEDING TIME OF RYEGRASS ON GROWTH AND YIELD COMPONENTS OF WHEAT (Triticum spp.) IN JIMMA ARE, SOUTH WEST ETHIOPIA
}

\author{
Haile Terefe ${ }^{1}$, EwnetuDenberu ${ }^{2}$, Abebe Woldesenbet ${ }^{* 3}$ \\ $1,2,{ }^{* 3}$ Department of Horticulture and Plant Sciences, Jimma University College of Agriculture \\ and Veterinary Medicine (JUCAVM), P.O.Box 307, Jimma, ETHIOPIA
}

DOI: https://doi.org/10.29121/granthaalayah.v4.i10.2016.2499

\section{ABSTRACT}

The experiment was conducted at Jimma University College of Agricultures and Veterinary Medicine (JUCAVM) under field condition to determine the effects of different weeding time of Ryegrass on growth and yield components of Wheat (Triticum spp.) The experimental design used was randomized complete block design (RCBD) and each of the experimental treatment was replicated three times. A Wheat cultivar, Digalu was grown with Ryegrass and different weeding time of Ryegrass T1 (weeding 15-45 DAS), T2 (weeding 30-60 DAS), T3 (weeding 45-75 DAS), T4 (weed free) and T5 (no weeding) were used as a treatment. Data were recorded on Wheat Plant height, Stem thickness, Number of tillers; Spike length and Spike number. The result revealed that various weeding time of Ryegrass statistically (p $\leq 0.05)$ affected Plant height, Stem thickness, Number of tillers; Spike length and Spike number. The maximum values of all the parameters were recorded in the (15-45 DAS) except for Plant height and Stem thickness. Whereas, the minimum values of these parameters were recorded from (45-75 DAS) except for Plant height. It is advisable for growers to remove the Ryegrass before the critical weed-crop competition period which is most probably (15-45 DAS) to keep the crop weed free at this period.

Keywords:

Wheat; Ryegrass; Weed removing; Weed competition DAS (Days After Sowing).

Cite This Article: Haile Terefe, EwnetuDenberu, and Abebe Woldesenbet, "EFFECTS OF DIFFERENT WEEDING TIME OF RYEGRASS ON GROWTH AND YIELD COMPONENTS OF WHEAT (Triticum spp.) IN JIMMA ARE, SOUTH WEST ETHIOPIA" International Journal of Research - Granthaalayah, Vol. 4, No. 10 (2016): 111-117.

\section{INTRODUCTION}

Wheat (Triticum spp.) is a cereal grain, originally from the Levant region of the Near East but now cultivated worldwide (Peter, 2009) ${ }^{[12]}$. In 2013, world production of Wheat was 713 million tons, making it the third most-produced cereal after maize (1,016 million tons) and rice (745 
million tons) (FAO Stat, 2015) ${ }^{[4]}$.Average yield of wheat in Ethiopia(1.3 t/ha) Hailu (2003), ${ }^{[7]}$ is very low compared to New Zealand, Netherlands, Ecuador and France (8.9, 8.6, 8.0 and $7.6 \mathrm{t} / \mathrm{ha})(\mathrm{FAO}, 2013){ }^{[5]}$.Ethiopia is the second largest wheat producer in sub-Saharan Africa, after South Africa. Although most of the wheat grown in Ethiopia is bread Wheat, there is some durum wheat which is often grown mixed with bread Wheat. Wheat is among the most important crops in Ethiopia, ranking fourth in total cereals production next to Maize, Sorghum and Teff $(\mathrm{CSA}, 2009)^{[2]}$.

Studies indicated that crop losses due to Weed competition throughout the world as a whole, are greater than those resulting from combined effect of Insect pests and diseases (Gella et al., 2013) ${ }^{[6]}$. There are innumerable reports on negative effects of Weeds on crop plants (Javaid et al., $2007)^{[8]}$ thus cause huge yield losses (Rathore et al., 2014) ${ }^{[13]}$. Unchecked weed growth reduces crop yield up to $57 \%$ (Singh et al.,1997) ${ }^{[16]}$.Weed infestation may reduce yield by 45.5 to $63.9 \%$ (Reddy and Reddi, 2002) ${ }^{[14]}$, in Wheat while reduced up to $92 \%$ by competition from Ryegrass (Dickson et al., 2011) ${ }^{[3]}$.

Rye grass can germinate, emerge, and establish over a range of environment. As it is in the same family with Wheat, Barley and Oat, it is known to affect the growth of Wheat, Barley, Oat and other crops by competing for each requirements of Wheat. In Wheat, yield reductions depend on the relative densities of the Weed and crop, relative times of emergence, staying with crops, weeding and resources available to each species. Ryegrass affects Wheat tillers and spikes to decrease in number, stem thickness decrease or become thin and spikes size become small but plant height increase as they compete for light conditions (Bond et al, 2014; Nandula et al, 2009) [1] [10]

Weeds are one of the major constraints of Wheat production and Weed control is the key Factor in increasing yield (Lopez-Granados, 2011; Shehzad et al., 2012) ${ }^{[9][15]}$. Weed control has been observed as one of the most important practice in crop production because good Weed control will ensure maximum yield and high quality of farm produce (Njoroge, 1999) ${ }^{[11]}$.

According to Hailu (2003) ${ }^{[7]}$, despite the importance of Wheat in Ethiopia, the mean national yield (1.3 t/ha) is $24 \%$ below the mean yield of Africa and $48 \%$ the global due to Weed infestation. Therefore, the objective of this study was to investigate effects of different weeding time of Ryegrass on growth and yield components of Wheat (Triticum spp.) under field condition.

\section{MATERIALS AND METHODS}

Description of the study area: The experiment was conducted under field condition in the year 2016 at Jimma University College of Agricultures and Veterinary Medicine in Oromia region in Jimma zone, South West part of Ethiopia. Geographically the area is located at about $7^{\circ}, 33^{\circ} \mathrm{N}$ Latitude and $36^{\circ} \mathrm{S}, 57^{\circ} \mathrm{E}$ longitude at altitude of 1710 meters above sea level (m.a.s.l). The mean maximum and minimum temperature are $26.8^{\circ} \mathrm{c}$ and $11.4^{\circ} \mathrm{c}$ respectively and the mean maximum and minimum humidity is $91.4 \%$ and $31.2 \%$ respectively. The mean annual rain fall of the area is 
estimated to be $1500 \mathrm{~mm}$. The soil type of this area is characteristically reddish brown clay soil with $\mathrm{P}^{\mathrm{H}}$ of 5.06-6.00.

Materials used: Ryegrass seed, clean Wheat seed (Digalu cultivar), digging material, shovel, meter and rope were used.

Treatments and experimental design: The experiment was carried out on $33.6 \mathrm{~m}^{2}$ consisted of 5 treatments: $\mathrm{T}_{1}$ (weeding 15-45 DAS), $\mathrm{T}_{2}$ (weeding 30-60 DAS), $\mathrm{T}_{3}$ (weeding 45-75 DAS), $\mathrm{T}_{4}$ (weed free) and $\mathrm{T}_{5}$ (no weeding). The experiments were laid out as completely randomized block design (CRBD) replicated three times. Thus, there were $5 \times 3$ treatments, which were replicated three times, resulting in 15 experimental units. Each treatment was conducted on $1.05 \mathrm{~m}$ by $1 \mathrm{~m}$ plot size and replicated three times with 70 seeds of Ryegrass and Wheat per plot except $\mathrm{T}_{4}$ (weed free) sown only Wheat seed. The spaces between plots and blocks used were $0.6 \mathrm{~m}$ and $0.7 \mathrm{~m}$ respectively.

\section{PROCEDURES FOR SITE PREPARATION}

1) The land was ploughed three times with oxen

2) $33.66 \mathrm{~m}^{2}$ of land was measured with meter which was $7.65 \mathrm{~m}$ by $4.4 \mathrm{~m}$ and checked by Pythagoras theorem

3) The field was divided in to three blocks and each block was divided in to five plots of $1.05 \mathrm{~m}$ by $1 \mathrm{~m}$ size and the plots were watered properly.

4) Finally 70 seeds of wheat (Digalu cultivar) were sown in row with spacing of $0.15 \mathrm{~m}$ and $0.10 \mathrm{~m}$ between rows and plants respectively and 70 seeds of ryegrass were sown in row by drilling. All treatments except the control group (weed free) were managed by weeding once a week to keep weed free for 30 days after starting weeding but all of them were watered, applied Urea and kept from other weeds in the same way.

\section{DATA COLLECTION AND ANALYSIS}

Data was collected from five central rows of each plot using the following parameters: Plant height $(\mathrm{cm})$, Stem thickness $(\mathrm{cm})$, Number of tillers, Spike length $(\mathrm{cm})$ and Spike number every week fifteen days after planting. Data of each parameter from each plot and replication was collected and analyzed by analysis of their variance (using ANOVA). The data was analyzed by SAS computer software.

\section{RESULTS AND DISCUSSIONS:}

Data was collected from five central rows of each plot. Five plants were selected and collected randomly from each plot. The following parameters were taken during data collection:

\section{PLANT HEIGHT}

Analysis of variance result showed that there were significant $(\mathrm{p} \leq 0.05)$ differences on Plant height and Spike number due to effect of Ryegrass weed (Table 1). Ryegrass weed has effect on Wheat plant height. As both of them compete for light so as to not to be shaded each other, the 
plant increases in height than that of weed free or usual plant height. This effect varies with the weed-crop competition period and time of weeding i.e. plant height increases during critical weed-crop competition period than the time after and before this period. This research result showed that there was significant difference in Plant height. This difference occurred between $\mathrm{T}_{4}$ (weed free) with an average height of $(60.09 \mathrm{~cm})$ and the rest treatments were showed no significant difference between treatment $T_{1}, T_{2}, T_{3}$ and $T_{5}$ with an average height of $(66.5 \mathrm{~cm}$, $65.9 \mathrm{~cm}, 67.5 \mathrm{~cm}$ and $67.7 \mathrm{~cm}$ ) respectively (table 2 below) as there was more or less crop-weed competition until the weed had been removed in treatment $T_{1}, T_{2}$ and $T_{3}$ and stay weedy in treatment $\mathrm{T}_{5}$.

\section{NUMBER OF TILLERS}

Very highly significant $(\mathrm{p}<.0001)$ differences were observed at Number of tillers, Spike number and Stem thickness due to effect of Ryegrass weed (Table 1 below).

As Ryegrass weed competes with Wheat crop for space, the Wheat lacks free space for tillering. This Ryegrass effect on Wheat tiller number varies with different growth stages of Wheat and Ryegrass. Tiller number of Wheat becomes seriously affected during tiller developing time of both Ryegrass and Wheat and less affected if the Ryegrass removed before this period. This research result showed high significant difference in tiller number of Wheat. There was significant difference between $T_{1}, T_{2}$ and $T_{3}$ with an average tiller of (15.3), (11.5) and (8.06) respectively. However, there was no significant difference between $\mathrm{T}_{4}$ and $\mathrm{T}_{1}$ with (16.2) and (15.3) tillers respectively and between $T_{3}$ and $T_{5}$ with tiller number of (5.8) and (8.0667) respectively (table 2 below).

\section{SPIKE LENGTH}

Ryegrass affects the spike length or size of the Wheat as it competes with Wheat for nutrients and other requirements to develop good spike height or size. The effect can be minimized by removing or weeding the Ryegrass before the critical weed-crop competition period. This research result revealed significant difference in spike length. There was significant difference between $T_{1}$ and $T_{3}$ with $(9.7333 \mathrm{~cm})$ and $(7.6733 \mathrm{~cm})$ average spike length respectively and between $T_{2}$ and $T_{5}$ with an average spike length of $(8.9567 \mathrm{~cm})$ and $(6.9933 \mathrm{~cm})$ respectively. But no significant difference was recorded between $\mathrm{T}_{1}, \mathrm{~T}_{2}$ and $\mathrm{T}_{4}$ which showed spike length of $(9.7333 \mathrm{~cm}, 8.9567 \mathrm{~cm}$ and $9.7933 \mathrm{~cm})$ respectively. And also no significant difference was observed between $T_{2}$ and $T_{3}$ with an average spike length of $(8.9567 \mathrm{~cm})$ and $(7.6733 \mathrm{~cm})$ respectively and between $T_{3}$ and $T_{5}$ with an average spike length of $(7.6733 \mathrm{~cm})$ and $(6.9933 \mathrm{~cm})$ respectively (table 2 ).

\section{SPIKE NUMBER}

Wheat crop which is infested by Ryegrass weed results in spike number reduction because the number of tillers becomes decreased and some of the tillers may not reach at spike bearing or heading stage due to the Ryegrass competition effect. This effect of Ryegrass on Wheat spike number varies with the growth stage of both plants i.e. early weed-crop competition followed by weeding before tillering has minimum effect whereas the effect becomes high if the wheat crop 
stays weedy during tiller formation and critical weed-crop competition period. This research result showed high significant difference of weeding time of Ryegrass on Wheat crop spike number. There was significant difference between $T_{1}, T_{2}$ and $T_{3}$ with an average spike number of (12.3333, 7.3 and 4.59) respectively and between $T_{2}$ and $T_{5}$ with an average spike number of (7.3) and (3.8) respectively. However, no significant difference was observed between $\mathrm{T}_{1}$ and $\mathrm{T}_{4}$ with an average spike number of (12.3333) and (12.4333) per plant respectively and between $\mathrm{T}_{3}$ and $\mathrm{T}_{5}$ with an average spike number of (4.59 and 3.8) per plant respectively (table 2).

\section{STEM THICKNESS}

Ryegrass has negative impact on Wheat stem thickness as it competes with Wheat crop for common resources such as nutrients, moisture, minerals and sunlight. The stem of the Wheat infested by Ryegrass becomes thinner than that of the Wheat which is weed free and early weed infested followed by removing the Ryegrass before critical weed-crop competition period. The research conducted showed high significant difference of Ryegrass weeding time on Wheat stem thickness (table 2 below). There was significant difference between each treatment which means that the Ryegrass affected the Wheat stem thickness staring from early growth up to the beginning of maturity with less to high severity. $\mathrm{T}_{1}(15-45 \mathrm{DAS})$ which resulted with an average stem thickness of $(1.83333 \mathrm{~cm})$ which was good thickness relative to $\mathrm{T}_{4}$ weed free with an average stem thickness of $(1.97333 \mathrm{~cm})$. However, the least stem thickness was recorded from $\mathrm{T}_{3}$ (45-75 DAS) with an average stem thickness of (1.48667) as compared to $\mathrm{T}_{1}$ and $\mathrm{T}_{4}$

Table 1: Mean square values for Plant hight, Tiller number, Spike length, Spike number and Stem thickness of wheat

\begin{tabular}{llllllr}
$\begin{array}{l}\text { Source of } \\
\text { Variation }\end{array}$ & Df & \multicolumn{5}{c}{ Mean squares } \\
\hline & & PH & NT & SL & SN & ST \\
Treatment & 4 & $6.92^{*}$ & $42.1^{* * *}$ & $7 *$ & $121.24^{* * *}$ & $121.72^{* * *}$ \\
Error & 8 & 4.3303 & 1.45916 & 0.6723 & 0.42156 & 0.0016133 \\
Total & 14 & & & & & \\
\hline DF =Degrees of freedom, PH= Plant height, NT= Number Tiller, SL= Spike Length, SN = Spike \\
Number, ST= Stem Thickness, *=significant at 5\% probability level, ***-very high significant at \\
$\leq .0001$
\end{tabular}


Table 2: Effect of weeding time of Ryegrass on plant height, tiller number, spike length, spike number, and stem thickness

\begin{tabular}{|c|c|c|c|c|c|}
\hline \multirow{2}{*}{$\begin{array}{l}\text { Treatments } \\
\text { (weeding time) }\end{array}$} & \multicolumn{5}{|c|}{$\begin{array}{l}\text { treatments' } \\
\text { mean }\end{array}$} \\
\hline & & & parameters & & \\
\hline & $\begin{array}{l}\text { plant } \\
\text { height }(\mathrm{cm})\end{array}$ & $\begin{array}{l}\text { tiller } \\
\text { number }\end{array}$ & $\begin{array}{l}\text { spike } \\
\text { length }(\mathrm{cm})\end{array}$ & $\begin{array}{l}\text { spike } \\
\text { number }\end{array}$ & $\begin{array}{l}\text { stem } \\
\text { thickness }(\mathrm{cm})\end{array}$ \\
\hline 15-45 DAS & $66.533 a$ & $15.3667 \mathrm{a}$ & $9.7333 a$ & $12.3333 a$ & $1.83333 b$ \\
\hline 30-60 DAS & $65.953 \mathrm{a}$ & $11.5667 \mathrm{~b}$ & $8.9567 \mathrm{ab}$ & $7.3 b$ & $1.62 \mathrm{c}$ \\
\hline 45-75 DAS & $67.56 a$ & $8.0667 \mathrm{c}$ & $7.6733 b c$ & $4.59 c$ & $1.48667 \mathrm{~d}$ \\
\hline $\begin{array}{l}\text { WEED FREE } \\
\text { STAY }\end{array}$ & $60.093 b$ & $16.2667 \mathrm{a}$ & $9.7933 a$ & $12.4333 a$ & $1.97333 \mathrm{a}$ \\
\hline WEEDY & $67.787 \mathrm{a}$ & $5.8 \mathrm{c}$ & $6.9933 c$ & $3.8 \mathrm{c}$ & $1.34 \mathrm{e}$ \\
\hline $\mathrm{CV}$ & 3.17288 & 10.58376 & 9.501432 & 8.024345 & 2.433339 \\
\hline LSD & 3.9181 & 2.2744 & 1.5439 & 1.2225 & 0.0756 \\
\hline
\end{tabular}

Means within the same column followed by different letter are significantly different at $\mathrm{P} \leq 0.05$, LSD=Least Significant Difference, CV=Coefficient Variance, DAS=Days After Sowing

\section{CONCLUSION}

Generally, being able to determine the growth stage of Wheat and Ryegrass at which they compete more, less or no competition is a crucial requirement to manage and accomplish different cultural practices properly and at correct time during the growing season. Fertilizers, pesticides and other chemicals should or should not be applied at certain points during the plant growth. By understanding what stage the plant is in, can be determined the correct cultural practices. Depending on this research result, the approximate correct time of Rye weeding or removing from the Wheat crop in the field should be at the early growth stage before tiller formation stop and reach at critical weed-crop competition period which is $15-45$ Days After Sowing.

\section{ACKNOWLEDGEMENTS}

The Authors would like to thank Jimma University College of Agricultures and Veterinary Medicine (JUCAVM) for funding the research expenses and providing all the necessary facilities to carry out the research.

\section{REFERENCES}

[1] Bond,J.A.,Eubank,T.W.,Bond, R.C., Golden, B.R. and Edwards, H.M.(2014) GlyphosateResistantItalian Ryegrass (Loliumperenne ssp. multiflorum) Control with Fall-Applied Residual Herbicides. Weed Technology, 28, 361-370. http://dx.doi.org/10.1614/WT-D-13-00149.1 
[2] CSA. September - December 2009. Report on Area and Production of Major crops. Ethiopian Agricultural Sample Survey Private Peasant Holdings, Meher Season (2009/10 (2002 E.C.)) - Volume IV.Statistical Bulletin 446 Addis Ababa: Central Statistical Agency. [various years and numbers]

[3] Dickson JW, Scott RC, Burgos NR, Salas RA, Smith KL. 2011. Confirmation of glyphosate resistant Italian ryegrass (Lolium perenne ssp. multiflorum) in Arkansas. Weed Technology 25, 674-679.

[4] FAO Stat. Retrieved 27 January 2015.

[5] FAO (Food and Agricultural Organization).2013. Statistical Year Book. MO. UN, Italy, 1-289.

[6] Gella D, Ashagre H, Negewo T. 2013. Allelopathic effect of aqueous extracts of major weed. Journal of Agricultural Crop Research 1, 30-35.

[7] HailuGebre-Mariam, 2003. Wheat production and research in Ethiopia, IAR, Addis Ababa Ethiopia.

[8] Javaid A, Bajwa R, Rabbani N, Anjum T. 2007.Comparative tolerance of six rice (Oryza sativa L.) genotypes to allelopathy of purple nutsedge (Cyperus rotundus L.). Allelopathy Journal 20, 157-166.

[9] Lopez-Granados F. 2011. Weed detection for sitespecific weed management: mapping and real-time approaches. Weed Research 51, 1-11.

[10] Nandula, V.K., Poston,D.H. and Reddy, K.N. (2009) Seed Germination Differences between Glyphosate-Resistant and -Susceptible Italian Ryegrass Populations. Seed Technology, 31, 123-131

[11] Njoroge JM. 1999. 17 East African Biennial WeeScience Conference Proceedings, 6571.

[12] Peter R. (2009), "Wheat", Journal of Experimental Botany 60 (6): 1537-1553, doi:10.1093/jxb/erp058

[13] Rathore M, Singh R, Choudhary PP, Kumar B.2014. Weed Stress in Plants. In: Approaches to Plant Stress and their Management. Springer India. India, 255-265.

[14] Reddy TY, Reddi GHS. 2002. Weed management, In. Principles of Agronomy, Kalyani Publishers, New Delhi, India, 418.

[15] Shehzad MA, Maqsood M, Anwar-ul-Haq M,Niaz A. 2012. Efficacy of various herbicides against weeds in wheat (Triticum aestivum L.). African Journal of Biotechnology 11, 791-799.

[16] Singh RK, Singh DK, Singh RP. 1997. Weed crop competition in wheat as affected by different weed species. Indian Journal of Weed Science 29, 69-71. 